\title{
PRODUCT ABUNDANCE, PRODUCT DELIVERY AND PRICE OF PRODUCT AS DETERMINANTS OF ONLINE BUSINESS PROFIT PERFORMANCE
}

\author{
Syaza Fahzlin Mohd Fahrughazi ${ }^{1}$ and Amrizah Kamaluddin ${ }^{2 *}$ \\ ${ }^{1}$ Malaysia Rail Link Sdn Bhd \\ ${ }^{2}$ Faculty of Accountancy, \\ Universiti Teknologi MARA Puncak Alam, Selangor, Malaysia
}

\begin{abstract}
With the increasing number of small and medium enterprises (SMEs) in Malaysia, most young entrepreneurs have started to use the internet as their business platform. However, the issue faced by these SMEs is maintaining their profit performance and long-term business sustainability. In maintaining their profit performance, entrepreneurs need to ensure they have product abundance, provide the best service delivery and offer the best price in the market. Hence, the objective of this research was to examine the relationship between an online business performance with the three main pillars of online business - product abundance, product delivery and product price. 210 registered SMEs located in the Klang Valley were chosen as the survey respondents. The result indicates that, product abundance and product price have a significant relationship with the performance, while product delivery had no significant relationship. This study proved that price of products offered by online business is crucial in maintaining customers' satisfaction that is closely related to sales and performance. The findings of the study assists the entrepreneurs in developing their business while contributing to the nation's economy when more potential SMEs' businesses with an online capability are able to penetrate into the international market and compete globally.
\end{abstract}

Keywords: online business, product abundance, product delivery, price of product, profit performance

\section{ARTICLE INFO}

\section{Article History:}

Received: 30 June 2020

Accepted: 8 June 2021

Published: 31 August 2021

* Corresponding Author: Amrizah Kamaluddin. E-mail: amrizah@uitm.edu.my 


\section{INTRODUCTION}

Over the past decades, the internet has grown rapidly worldwide. Nowadays, most businesses are using information and communication technology (ICT) to explore the development of their business regardless of the business size (Hashim, 2015). Thus, 'online business' phenomena has mushroomed around the world including Malaysia as more businesses depend on the internet for growth and the increasing demand of online purchasing (Khan, Awan, \& Ho, 2018). Since then, online businesses have been very popular among buyers and sellers as these eliminate marketing barriers such as distance and time difference. Furthermore, according to Brunswicker and Vanhaverbeke (2015), small and medium enterprises (SMEs) are a group of firms with no subsidiary bonds under them as they are independent firms that have different characteristics compared to other big sized companies. Meanwhile, the definition of an online business according to Tan, Chong, Lin, and Eze (2009) is "organizations that use the internet through web sites as platforms of communications within and between the organizations and their stakeholders".

The importance of SMEs towards the national economic growth increased rapidly as technology began to play its part in 2007 with an internet penetration of almost half the size of the Malaysian population (Tan et al., 2009). Therefore, digital business is hence important for Malaysians to utilize. Tan et al. (2009) also agree that ICT helps companies to enter larger markets, competing with other bigger organizations with cost efficiency. Tan et al. (2009) also add that online businesses have been very popular among buyers and sellers, eliminating many barriers such as distance and also time difference. Hence the use of the internet or e-commerce to expand business activities will help SMEs to go further than just the borders of their area with innovation and technological adaptation (Suwannapha, 2016). According to Tan et al. (2009), this parallel strong growth between the number of SMEs and online businesses is due to the Malaysian government's contribution in creating some initiatives to encourage entrepreneurs in going further into the global market.

The life length of most SMEs in Malaysia is seen lightly regardless of its big contribution in terms of gross domestic product growth. Due to challenges such as high competition in terms of pricing, mobility and 
familiarity of the product (Suwannapha, 2016), most SMEs especially sole proprietorships do not last long enough in the market. Due to lack of product abundance in a business, most SMEs do not survive in the market. Their customers are easily attracted to other similar shops (Lee, Eze, \& Ndubisi, 2011) that offer a wider selection of products at different business mediums such as the website, social media and many more. Lee et al. (2011) also emphasized that in order to engage in an online business, Malaysian SMEs should understand their product marketplace and potential buyers so that they can effectively develop their operations via online facilities. Hence, most SMEs are not able to maintain their profit performance due to low product abundance in the business.

Customer satisfaction is also affected by the product delivery service provided by a business. Some online businesses take product delivery lightly because the payment transaction has already been done before the purchased product is delivered. However, due to an inefficient product delivery service, most online businesses lose their potential customers over time because of their failure to keep the existing customers satisfied and also the power of word-of-mouth among internet users that gives a negative impact based on unsatisfied customers (Holloway \& Beatty, 2008). Therefore, the result from increasing operational costs and poor delivery service leads to declining of a business profit performance.

Although with the borderless information obtained from the internet, a business is still at risk when competing with other online businesses in the market that are mushrooming through the internet. In addition, an online business SME does not only compete with businesses that use e-commerce but also traditional-based businesses such as retail shops, pop-up stores and stalls in shopping malls. Therefore, the determination of product pricing may result in enhancing the business profit performance or risking the business. The business is unable to compete further with other shops that have better price offers. Thus the current study examined whether product abundance, delivery and price influence the performance of an online business or digital entrepreneurs. 


\section{LITERATURE REVIEW}

\section{Profit Performance}

The performance of SMEs is often determined by several factors that may be the key drivers for better performance and longer life span in the market. Past studies have discussed on factors such as business financing, resource capabilities (Prange \& Pinho, 2017) and internationalization of SMEs (Nasiri, Sultan, \& Alleyne, 2018; Prange \& Pinho, 2017). These factors are classified under business resources that act as competitive advantage to determine business performance (Nasir, Al Mamun, \& Breen, 2017).

According to Omondi and Mbugua (2017), a profit performance to some businesses is the effectiveness of an organization to achieve its purpose with continuous improvement in its profitability status. As the survival of SMEs in a competitive business environment may portray that the business has a good performance (Nasir et al., 2017), having competitive value in the form of information technology such as IT assets, database, internet usage and many more which may lead to better sustainability of the business that will improve its profit performance (Zhu \& Kraemer, 2002).

Therefore, past research has proven that improving profit performance for SMEs is very important in maintaining their life-span in the market as well as improving a country's economic status. Furthermore, onlinebased SMEs obtain a competitive advantage that puts them a step ahead in increasing their profit performance by the IT-resources that they possess.

\section{Product Abundance}

Online shopping provides a wider variety of product selection offered online. It provides a new form of convenience in terms of time saving, effort savings and also accessibility through the website at any desired hour. Thus, many shoppers prefer shopping online rather than at retail shops (Wolfinbarger \& Gilly, 2001). Shoppers also expect to find a selection of products online including their desired complete line of products from their favourite retailers. 
Based on Guo, Zhao, Jin, and Zhang's (2010) study, entrepreneurs can benefit from online business by posting more information and advertisements about their products using the platform while potential customers are able to browse for the products they desire. Hence there will be more product selection on the virtual shelves. Buhalis and Law (2008) also have the same opinion on this with their opinion that quick identification of customers' needs by providing the latest products and services according to demand is key to success of an online business.

Product abundance in online business platforms does not only reflect a positive attitude among customers, but they are also able to have more control in making product comparisons, price comparisons and the right choice to purchase (Guo et al., 2010). Guo et al. (2010) also added that product abundance will be more useful in terms of information protection and facilitating conditions.

\section{Product Delivery}

Many past studies including Holloway and Beatty (2008), Gallino and Moreno (2014), Buhalis and Law (2008) and Jiang, Yang, and Jun (2013) believe that an online business possesses different satisfactory influences as compared to traditional service and this includes the delivery service that is crucial in selling and buying through the internet. In another study, on time delivery and ease of navigation have been proven as significant elements of the online service experience (Holloway \& Beatty, 2008; Wolfinbarger \& Gilly, 2001) because it relates closely with customers' satisfaction that will keep the customers to repetitively use the business website and also spread a positive review about the business.

Yang, Peterson, and Cai (2003) found that fast delivery and correct order affects greatly the level between satisfier or dissatisfier factors. This is because as customers purchase an item without physically viewing them, they are more eager to receive the purchased product instantly. Moreover, timeliness in terms of on time delivery that includes efficient delivery tracking and a product's condition are among factors of how delivery service actually gives a great impact on the business profitability factor as it reflects a customer satisfaction while doing online shopping (Jiang et al., 2013; Yang et al., 2003). 
Additionally, Bednarz and Ponder (2010) compared online shopping to traditional physical shopping, and showed that traditional shopping needs to use more effort in gaining the possession of buying a product such as travelling to the shop, having to queue up to pay for the product and many more. Meanwhile despite the delivery waiting time, online shoppers on the other hand can obtain the product easily with lesser effort by just clicking through the internet. Regardless of the waiting period, online shoppers find purchasing items virtually to involve less fuss and effort as their item arrives at their doorstep within a few days after purchase (Bednarz \& Ponder, 2010).

\section{Price of Product}

Chiang and Dholakia (2003) stated that what grabs the attention of customers to shop online is the promise of greater savings. They further explained that there are two main reasons why consumers choose to shop online over physical stores: better convenience and greater savings. Both factors can be seen when customers are able to reduce search cost by comparing products online within few clicks. Chiang and Dholakia (2003) concluded that $85 \%$ of customers found online shopping to be more convenient as they found price comparisons much easier.

Although $\mathrm{Ku}$ (2012) argues that there are other factors than price reduction online companies should take into account. It is important to for online auctions to succeed by offering high quality products with reasonable prices (Dimoka et al., 2012). Lin, Chen, and Song (2009) emphasized that the price of a product is one of the most important factors that influences the decision of users to join an online purchasing group. Furthermore, as price dispersion occurs in the online-shop world, the reputation of businesses that use the internet as the selling platform also influences their pricing strategy (Karakaya \& Barnes, 2010).

On the other hand, according to Moon, Chadee, and Tikoo (2008), if an online business provides products that meet customers' needs and demands, customers are willing to pay higher costs for the product as price becomes a less important factor to why they shop online with lesser incentives to compare among shops. Dimoka et al. (2012) also believe that online markets are able to improve social welfare by using the internet to offer lower prices. Furthermore, the concept of price premium offered among online business 
owners has shown to influence transaction activity because it has become a key outcome for online auctions to succeed (Dimoka et al., 2012)

\section{HYPOTHESES DEVELOPMENT}

Product abundance in a business is very important for customers to have the freedom to browse through each product for decision making. According to Chiang (2010), the existence of two types of customers which are retail customers and direct customers creates a competitive advantage for businesses that maintain product availability in their business. Chiang (2010) further explained when an out-of-stock period occurs in retail shops customers are willing to switch from buying retail to buying direct on the internet.

Furthermore, product abundance also enables customers to have a bigger option in choosing their desired products. Not only customers are eased by the different information provided with each product displayed (Guo et al., 2010), product abundance also results in satisfying customers who will contribute more to the profit performance of a business (Holloway \& Beatty, 2008). Hence, it is important for an online business to maintain product abundance throughout the selling period. With this, the first research hypothesis was developed.

H1: There is a significant relationship between product abundance and profit performance of an online business.

Since online business connects with customers directly on the internet without any physical platform, the delivery of the product to customers is very important to maintain customers' trust and a positive word-of-mouth. Aspects such as fast delivery (Holloway \& Beatty, 2008), easier buying process (Bednarz \& Ponder, 2010) and correctly delivered item in good condition when received (Jiang et al., 2013) are crucial when handling the delivery process of customers' purchased products.

As fast delivery will also facilitate customers from having to go through a lesser waiting time (Bednarz \& Ponder, 2010), shows that customers will prefer to purchase their desired item online rather than having to go through 
a fussy buying process such as in retail shops from squeezing through the sardined store on weekends to queuing up at the cashier for payment. As more customers prefer to go online, online business owners are advantaged by this positive opportunity to increase their profit performance. Based on this discussion, it is hypothesised that:

H2: There is a significant relationship between delivery of a product and profit performance of an online business.

In setting up business on the internet, the price of the product still plays an important part to greatly compete not only with retail shops but also among other online businesses that have been mushrooming in the market over the decade. According to Ryu and Han (2010), most customers take into account the price perceptions of their desired product upon making decisions; such as the reasonability of the price or whether it is cheaper than other online shops. Han and Hyun (2015) in addition, supported this statement by stating that price reasonableness of a product results in customer's loyalty towards a business. As the price of a product is also important for an online business to enhance its profit performance, the third hypothesis was:

H3: There is a significant relationship between price of a product and profit performance of an online business.

\section{RESEARCH METHOD}

This study applied a quantitative method which used descriptive and hypotheses testing to achieve the objectives. A list of companies extracted from the SME Corporation Malaysia's website was chosen and the list was narrowed down to registered SMEs located around the Klang Valley, Selangor.

The study used the simple random sampling technique. According to 2017 SME Corporation Malaysia's list of SME firms, there were around 22, 429 firms registered as SMEs around Malaysia and 210 of them were in the Klang Valley which made the total number for the entire population for this study. Based on the total figure, the reliable sample that should be taken 
would be 130 companies in accordance with the sample size determinants by Sekaran and Bougie (2016) to make the data reliable for analysis. This survey was conducted through three approaches - online survey form using Google Document, electronic mail and door-to-door to shops that had their own official business website which provided buying and selling facilities.

The questionnaire created for the respondents consisted of five main parts - Business Performance, Product Abundance, Product delivery, Price of Product and Demographic Information. The questionnaire consisted of 37 questions. Part One reflected the dependent variable of this study which is profit performance of an online business. Part One consisted of nine questions concerning the respondent's business profit performance from both the financial and non-financial perspective. For non-financial performance, the respondents were asked on customers' loyalty, web traffic, yearly sales, cost reduction and positive word of mouth among internet users who are also the business' potential buyers (Gallino \& Moreno, 2014; Kraaijenbrink, Spender, \& Groen, 2010; Parker \& Castleman, 2009).

Part Two, Three and Four were the three independent variables of the study which are the pillars of online business. To measure product abundance, Part Two consisted of eight questions related to how the business manages the in and out of their products, the variety and wide choices of products offered, and also the exclusivity of their products displayed on the Internet (Guo et al., 2010; Holloway \& Beatty, 2008). In Part 3, nine questions are asked to measure the efficiency of the business in handling product delivery. These questions mainly focussed on the delivery service of the products purchased by customers, the delivery costs incurred, and also the condition of the products upon arrival (Jiang et al., 2013; Bednarz \& Ponder, 2010; Huang, Kuo, \& Xu, 2009). In the final part of variable measurement which was Part 4, the seven questions presented were to measure the price of the product and the special features most respondents with online business offer to their customers in the form of discounts, promotions and availability of low-priced products (Dimoka et al., 2012; Han \& Hyun, 2015). Respondents were required to indicate their response on each item asked. These four parts of the questionnaire used a four-point Likert scale from strongly disagree (1) to strongly agree (4) in measuring the variables in each part. 


\section{RESULTS AND DISCUSSION}

\section{Descriptive Analysis}

The questionnaires were distributed to SMEs which consisted of businesses from different fields and backgrounds. Table 1 summarizes the distribution of 80 responses that shows four different main business fields and one field under the category of 'Others' for respondents whose business fields are not mentioned in the questionnaire. Based on the data analysed, around $16 \%$ of respondents who selected 'Others' are running business such as beauty and health products, property, pet supplements, car and phone accessories, toys, lady's accessories and many other services. Food and beverages $(F \& B)$ had the highest frequency of participation in this study with 20 SMEs taking part in answering the survey while cosmetics and clothings share the same response rate of $24 \%$ each taking both as the second highest responses received from this field of business.

Table 1: Frequency and Percentage by Business Fields

\begin{tabular}{lcc}
\hline \multicolumn{1}{c}{ Business Field } & Frequency & Percentage (\%) \\
\hline Digital (gadgets \& smartphones) & 9 & 11.25 \\
Clothing & 19 & 23.75 \\
Cosmetics & 19 & 23.75 \\
Food and Beverages & 20 & 25.00 \\
Others & 13 & 16.25 \\
TOTAL & $\mathbf{8 0}$ & 100 \\
\hline
\end{tabular}

$70 \%$ of the online businesses have been operating for only one to two years. $25 \%$ of the respondents claimed that they have operated their business for less than 5 years while $5 \%$ had been in the market for more than 5 years.

\section{Normality Test, Correlations and Regression Analysis}

Table 2 depicts the normality test performed on the variables of this study. Based on the skewness and kurtosis for independent variables, the range was between 2 and -2 . The skewness of product abundance, product delivery and price of the product were $0.097,-0.212$ and 0.200 respectively. The kurtosis for all of the three independent variables were also within the 
range of 2 and -2 which are -0.876 for product abundance, -0.221 for product delivery and -1.265 for price of product. Since the data for skewness and kurtosis were between 2 and -2 , the data was considered as normal (Field, 2013).

Table 2: Skewness, Kurtosis, Mean and 5\% Trimmed mean

\begin{tabular}{lccc}
\hline \multicolumn{1}{c}{ Variables } & Skewness & Kurtosis & 5\% Trimmed Mean \\
\hline Profit Performance & -0.318 & -0.275 & 3.2674 \\
Product Abundance & 0.097 & -0.876 & 3.2170 \\
Product Delivery & -0.212 & -0.221 & 3.3858 \\
Price of Product & 0.200 & -1.265 & 3.3651 \\
\hline
\end{tabular}

As in Table 3, product delivery was negatively related to product abundance with a Pearson correlation coefficient of $r=-0.474$ and the significance value was less than 0.001 . Product abundance was positively related to profit performance of $\mathrm{r}=0.584$ and significant at $p<0.001$. Finally, price of product appeared to be positively related to profit performance with $\mathrm{r}=0.573, p<0.001$.

Table 3: Correlations of Variables

\begin{tabular}{lcccc}
\hline & $\begin{array}{c}\text { Profit } \\
\text { Performance }\end{array}$ & $\begin{array}{c}\text { Product } \\
\text { Abundance }\end{array}$ & $\begin{array}{c}\text { Product } \\
\text { Delivery }\end{array}$ & $\begin{array}{c}\text { Price of } \\
\text { Product }\end{array}$ \\
\hline Profit Performance & 1 & & & \\
Product Abundance & $0.584^{* * *}$ & 1 & & \\
Product Delivery & $0.399^{* * *}$ & -0.474 & 1 & \\
Price of Product & $0.573^{* * *}$ & 0.681 & 0.505 & 1 \\
\hline Note: "' significant at p-value $<0.001$ & & & &
\end{tabular}

Table 4: Regression Analysis: The Relationships between Product Abundance, Product Delivery and Price of Product with Profit Performance

\begin{tabular}{lcccc}
\hline \multicolumn{1}{c}{ Variables } & Beta & Std. Error & Beta & p-value \\
\hline Product Abundance & 0.324 & 0.118 & 0.340 & $0.007^{* *}$ \\
Product Delivery & 0.093 & 0.110 & 0.089 & 0.401 \\
Price of Product & 0.329 & 0.140 & 0.296 & $0.021^{* *}$ \\
$\mathrm{R}^{2}$ & 0.404 & & & \\
Adjusted R & 0.380 & & & \\
F-Value & $17.144^{* * *}$ & & \\
df $(4,76)$ & & & \\
\hline
\end{tabular}


Table 4 presents the result of the multiple regression analysis between the independent variables being product abundance, product delivery and price of the product with the dependent variable of online business - profit performance. The result of $\mathrm{R}^{2}$ value was 0.404 . This indicated that only $40.4 \%$ of the variation in the response variable (profit performance) can be explained by the predictors in this study which were product abundance, product delivery and price of the product.

The result of $p$-value $<0.05$ indicated that the model was significant and thus this indicated that the model was good in analysing the influence of the three pillars of an online business on the profit performance of a business. The adjusted $\mathrm{R}^{2}$ value in the table indicates how much variance in the dependent variable can be explained by the model (Field, 2013). Adjusted $\mathrm{R}^{2}$ statistics corrects the $\mathrm{R}^{2}$ and provides better estimate hence the adjusted $\mathrm{R}^{2}$ value for the model was $38 \%$ which demonstrated a low variability explained by the independent variables.

The result explains that the effect of product abundance on profit performance of an online business SME is significant. $\mathrm{H}_{1}$ suggests that the product abundance significantly influences the profit performance of an online business. The result indicated that the beta for regression test was significant with value of 0.007 where p-value $<0.05$. In addition, since product abundance was positively related to the profit performance with coefficient of $\mathrm{r}=0.584$. Thus, $\mathrm{H}_{1}$ is accepted.

The result on product delivery and profit performance reflected a weak and insignificant relationship. Thus, $\mathrm{H}_{2}$ was not accepted. With regard to the relationship between price of the product and profit performance, the analysis indicated that the beta value of 0.021 was significant with $p$-value $<0.05$. Hence, $\mathrm{H}_{3}$ was accepted.

\section{CONCLUSION}

The study proved that most business owners agree on the importance of product abundance in their business in terms of giving customers larger options to choose between products and encouraging them to purchase more items that are displayed in the online store. This is consistent with 
Chiang (2010) who emphasized the importance of product selection of a business especially businesses that are built on the basis of technology and Internet platform.

For product delivery, although the research finding was not significant as compared to the other pillars of an online business, it is still considered as an important aspect that influences a profit performance. The results derived from past studies illustrate the significant relationship between product delivery and business' profit performance of an online-based SME (Bednarz \& Ponder, 2010; Chen, Yen, \& Chen, 2009; Huang et al., 2009). It is essential that a business pays attention to the service of delivery they are providing for their customers in sending the purchased products to their doorstep.

The price of the products is the most common aspect for a business to focus on regardless of what platform they use to run their business. Previous research done by Chiang and Dholakia (2003); Ku (2012); Han and Hyun (2015); Lin et al. (2009); Parasuraman, Zeithaml, and Malhotra (2005) confirmed that the price of products is imperative in attracting customers. This is because as the number of SMEs grows especially on the Internet that provides a borderless communication and a bigger field of buying platform, the market for an online business also becomes wider, which then creates a higher competition. Therefore, in order to maintain and enhance profit performance of an emerging or existing online business, the business should make a good decision in placing a reasonable and attractive price on each of their products.

\section{DIRECTION OF FUTURE RESEARCH}

The current study aimed to benefit online business entrepreneurs to have a clearer view on the success factors of an online business. This research can be expanded in various perspectives. In the current Covid-19 pandemic situation, online business is an essential platform to ensure the sustainability of SMEs. This context of research is thus crucial to both SMEs and the relevant authorities. Additional variables such as location of business, the attractiveness of the website and product reviews are recommended to be added into the current research model in order to determine enhanced profit 
performance. A bigger sample is also suggested to ensure the reliability and generalizability of the results.

\section{REFERENCES}

Bednarz, M., \& Ponder, N. (2010). Perceptions of retail convenience for in-store and online shoppers. Marketing Management Journal, 20(1), 49-65.

Brunswicker, S., \& Vanhaverbeke, W. (2015). Open innovation in small and medium-sized enterprises (SMEs): External knowledge sourcing strategies and internal organizational facilitators. Journal of Small Business Management, 53(4), 1241-1263.

Buhalis, D., \& Law, R. (2008). Progress in information technology and tourism management: 20 years on and 10 years after the Internet-The state of eTourism research. Tourism management, 29(4), 609-623.

Chen, J. V., Yen, D. C., \& Chen, K. (2009). The acceptance and diffusion of the innovative smart phone use: A case study of a delivery service company in logistics. Information \& Management, 46(4), 241-248.

Chiang, K.-P., \& Dholakia, R. R. (2003). Factors driving consumer intention to shop online: An empirical investigation. Journal of Consumer Psychology, 13(1-2), 177-183.

Chiang, W.-y. K. (2010). Product availability in competitive and cooperative dual-channel distribution with stock-out based substitution. European Journal of Operational Research, 200(1), 111-126.

Dimoka, A., Hong, Y., \& Pavlou, P. A. (2012). On product uncertainty in online markets: Theory and evidence. MIS Quarterly, 395-426.

Field, A. (2013). Discovering statistics using IBM SPSS statistics. Thousand Oaks, CA: Sage Publication. 
Gallino, S., \& Moreno, A. (2014). Integration of online and offline channels in retail: The impact of sharing reliable inventory availability information. Management Science, 60(6), 1434-1451.

Guo, X., Zhao, Y., Jin, Y., \& Zhang, N. (2010). Theorizing a two-sided adoption model for mobile marketing platforms. Paper presented at the International Conference of Information System, St, Louis, Missouri, United States.

Han, H., \& Hyun, S. S. (2015). Customer retention in the medical tourism industry: Impact of quality, satisfaction, trust, and price reasonableness. Tourism Management, 46, 20-29.

Hashim, J. (2015). Information communication technology (ICT) adoption among SME owners in Malaysia. International Journal of Business and Information, 2(2), 221-240.

Holloway, B. B., \& Beatty, S. E. (2008). Satisfiers and dissatisfiers in the online environment: A critical incident assessment. Journal of Service Research, 10(4), 347-364.

Huang, Y.-K., Kuo, Y.-W., \& Xu, S.-W. (2009). Applying importanceperformance analysis to evaluate logistics service quality for online shopping among retailing delivery. International Journal of Electronic Business Management, 7(2), 128-136.

Jiang, L., Yang, Z., \& Jun, M. (2013). Measuring consumer perceptions of online shopping convenience. Journal of Service Management, 24(2), 191-214.

Karakaya, F., \& Ganim Barnes, N. (2010). Impact of online reviews of customer care experience on brand or company selection. Journal of Consumer Marketing, 27(5), 447-457.

Khan, H. U., Awan, M. A., \& Ho, H. C. (2018). How do Chinese and Saudi customers perceive online service quality? A comparative study. The Journal of Business Inquiry, 13(2), 146-161. 
Kraaijenbrink, J., Spender, J.-C., \& Groen, A. J. (2010). The resource-based view: A review and assessment of its critiques. Journal of Management, 36(1), 349-372.

$\mathrm{Ku}$, E. C. (2012). Beyond price: how does trust encourage online group's buying intention? Internet Research, 22(5), 569-590.

Lee, C. H., Eze, U. C., \& Ndubisi, N. O. (2011). Analyzing key determinants of online repurchase intentions. Asia Pacific Journal of Marketing and Logistics, 23(2), 200-221.

Lin, P.-C., Chen, C.-C., \& Song, M.-H. (2009). Price dispersion of online air tickets for short distance international routes. The Service Industries Journal, 29(11), 1597-1613.

Moon, J., Chadee, D., \& Tikoo, S. (2008). Culture, product type, and price influences on consumer purchase intention to buy personalized products online. Journal of Business Research, 61(1), 31-39.

Nasir, W. M. N. b. W. M., Al Mamun, A., \& Breen, J. (2017). Strategic Orientation and Performance of SMEs in Malaysia. SAGE Open, 7(2), 2158244017712768 .

Nasiri, A., Sultan, B., \& Alleyne, A. (2018). Analysis of French SMEs' international competitiveness. Journal of Economics and Management Sciences, 1(1), 1-12.

Omondi, A. O., \& Mbugua, A. W. (2017). An Application of association rule learning in recommender systems for e-Commerce and its effect on marketing. IEEE Pan African Conference on Science, Computing and Telecommunications (PACT), Strathmore University, Nairobi, Kenya.

Parasuraman, A., Zeithaml, V. A., \& Malhotra, A. (2005). ES-QUAL: A multiple-item scale for assessing electronic service quality. Journal of Service Research, 7(3), 213-233.

Parker, C. M., \& Castleman, T. (2009). Small firm e-business adoption: A critical analysis of theory. Journal of Enterprise Information Management, 22(1/2), 167-182. 
Prange, C., \& Pinho, J. C. (2017). How personal and organizational drivers impact on SME international performance: The mediating role of organizational innovation. International Business Review, 26(6), 1114-1123.

Ryu, K., \& Han, H. (2010). Influence of the quality of food, service, and physical environment on customer satisfaction and behavioral intention in quick-casual restaurants: Moderating role of perceived price. Journal of Hospitality \& Tourism Research, 34(3), 310-329.

Sekaran, U., \& Bougie, R. (2016). Research methods for business: A skill building approach. Chichester: John Wiley \& Sons.

Suwannapha, T. (2016, July 5). "Small is the New Big" - Malaysian SMEs Help Energize, Drive Economy. The World Bank.

Tan, K. S., Chong, S. C., Lin, B., \& Eze, U. C. (2009). Internet-based ICT adoption: Evidence from Malaysian SMEs. Industrial Management \& Data Systems, 109(2), 224-244.

Wolfinbarger, M., \& Gilly, M. C. (2001). Shopping online for freedom, control, and fun. California Management Review, 43(2), 34-55.

Yang, Z., Peterson, R. T., \& Cai, S. (2003). Services quality dimensions of Internet retailing: An exploratory analysis. Journal of Services Marketing, 17(7), 685-700.

Zhu, K., \& Kraemer, K. L. (2002). E-commerce metrics for net-enhanced organizations: Assessing the value of e-commerce to firm performance in the manufacturing sector. Information Systems Research, 13(3), 275-295. 